\title{
UNCONSTITUTIONAL LEGAL SOLUTIONS ENSHRINED IN THE CODE OF CRIMINAL PROCEDURE OF 2014
}

\section{DOI: $10.47743 /$ rdc-2016-3-0004}

\section{Tudorel TOADER ${ }^{1}$}

ttoader@uaic.ro
Marieta SAFTA ${ }^{2}$

marieta.safta@ccr.ro

\section{Abstract}

This study continues the presentation on the development of the constitutional court's case-law, from ascertaining the unconstitutionality of the legal rule to ascertaining the unconstitutionality of the legal solution promoted by that rule with punctual respect to criminal procedure. The constitutional review transcends the strict boundaries of referrals brought before the Court in order to purify the legal system from those that reproduce legal solutions found to be unconstitutional. Thus, it is emphasized both the effect of sanctioning the rule which was the subject matter of the exception of unconstitutionality, and the preventive effect of constitutional review, by the inability of the legislature to resume a legal solution found unconstitutional, except where there is a change of the social and economic context.

Keywords: unconstitutional legal solutions; constitutional review; criminal procedure; constitutionalization of law

Continuing our approach to present legal solutions in the field of criminal proceedings, which began on the Code of Criminal Procedure of 1968, came into force on 1 January 1969, which was applicable until 1 February 2014, the date on which the new Code of Criminal Procedure entered into force, we will further refer to unconstitutional legal solutions enshrined in the latter normative act.

As previously, starting from the principle that "a legal solution found unconstitutional cannot be resumed through another normative act", this paper approaches the legal solutions enshrined in the Code of Criminal Procedure of 2014, which were declared unconstitutional, thus they cannot be resumed in any other regulation and the Constitutional Court's findings regarding them maintain their validity.

\footnotetext{
${ }^{1}$ Professor, PhD, Rector of "Al.I. Cuza" University of Iaşi, judge of the Constitutional Court of Romania (October 2006-July 2016).

${ }^{2}$ Associate Professor, PhD, Faculty of Law of "Titu Maiorescu" University of Bucharest, First assistant-magistrate of the Constitutional Court of Romania.
}

CONSTITUTIONAL NEWS 
1. In line with the requirements of the adversarial principle of the criminal trial, the legal solution which restricts the prosecutor's possibility to participate in the contradictory debate of evidence taken in the course of prosecution and not disputed by the parties is unconstitutional

The legal solution found unconstitutional was enshrined in Article 374 para. (7) second sentence of the Code of Criminal Procedure, provisions according to which: "The evidence gathered during the criminal prosecution and uncontested by the parties shall not be adduced again during the criminal proceedings. Such evidence is subject to the contradictory debate of the parties and is taken into consideration by the court in the deliberation".

The Court held that Article 131 of the Basic Law enshrines the prosecutor's key role in judicial activity, i.e. representative of the general interests of society, defender of the rule of law, and of the fundamental rights and freedoms of citizens. While the constitutional text refers to the protection of the legal order and of the citizens' rights and freedoms, Article 374 para. (7) second sentence of the Code of Criminal Procedure restricts the possibility for the public prosecutor to participate in the contradictory debate on evidence gathered during the prosecution and uncontested by the parties. The adversarial principle, by its very nature, is itself a guarantee of the right to a fair trial for the attainment and protection of the fundamental rights and freedoms, as it leads to the achievement of the constitutional objectives by the possibility of both the prosecution and the defence not only to inspect all documents, comments or evidence proposed by the judge, likely to influence his decision, but also to discuss or comment them. At the same time, the European Court of Human Rights ruled in its case-law that the adversarial principle does not concern solely the parties, but also the Public Ministry or even another independent jurisdiction participating, under national rules, in higher level proceedings, as is the case of the court of first instance (see, to that effect, judgement of 18 February 1997 in the case of Nideröst-Huber v. Switzerland, paragraphs $23,27,31)$. The limitation set forth in the criticised legal text is unconstitutional, because Article 131 para. (1) of the Basic Law sets out clearly and categorically the scope of prosecutor's powers, without referring to other cases laid down by law. It is true that Article 131 para. (2) states that "the Public Ministry exercises its powers through prosecutors working in prosecutor's offices, under the conditions of the law", but the reference to the conditions of the law concerns the organisation of prosecutor's offices and not the exercise of the tasks set out in para. (1). The constitutional legislature intended to confer a decisive role to the prosecutor in representing the general interests of society, since it placed the provisions relating to the Public Ministry under the Chapter on "Judicial Authority", and no organic law or ordinary can derogate from the constitutional texts. The public prosecutor takes part in the proceedings and contributes to the finding of the truth, reason why, in the course of a criminal 


\section{Unconstitutional legal solutions...}

prosecution, he collects and submits evidence, both for and against the suspect or the accused person, of its own motion or on request. The constitutional text, referring to the protection of the rights and freedoms of citizens, does not intent to convert the prosecutor into a lawyer of one of the parties, as his only task is to ensure compliance with the law in the proceedings that call into question such rights and freedoms. As we speak of criminal proceedings, it is undeniable that in this area, there are general interests to be defended, and, in the work of the judiciary, the Constitution established that the prosecutor will play this role and therefore his mandatory participation in criminal proceedings may not be formal in nature. It is therefore without doubt that the contradictory debate on evidence, in the conditions of the criticised legal text, affects legal order as established in the Constitution, which enshrines the role of the Public Ministry.

Decision no. 76 of 26 February 2015 on the exception of unconstitutionality of the second sentence of Article 374 para. (7) second sentence of the Code of Criminal Procedure, published in the Official Gazette of Romania, Part I, no. 174 of 13 March 2015.

\section{The legal solution that establishes a summary judgment based on written notes, in violation of the adversarial and orality principles is unconstitutional}

The legal solution found unconstitutional was enshrined in Article $549^{1}$ para. (2) of the Code of Criminal Procedure, provisions according to which: "The preliminary chamber judge shall communicate to the individuals whose rights or legitimate interests may be affected, a copy of the order, having the possibility of submitting written notes within 10 days as of the communication".

The Court noted that, according to Article $549^{1}$ of the Code of Criminal Procedure, the procedure conducted before the preliminary chamber judge in this matter presupposes a summary judgement, based on the written arguments submitted by the persons whose rights or legitimate interests have been affected; the audi alteram partem principle, the adversarial principle, and the public access principle, under which the public prosecutor and the parties involved in the proceedings have the right to inspect all the evidence and the observations submitted to the Court, as well as to present their case before the Court, need not be applied in this procedure.

From the perspective of adversarial aspect as a defining element of equality of arms and of the right to a fair trial, the Constitutional Court held that the legal rule should allow that the documents which are likely to influence the judge's be communicated to all parties of the criminal trial and include the possibility of all these parties to effectively discuss the observations submitted to the court. 
As concerns the right to an oral hearing, the Court noted that "only in certain debates conducted orally the trial can be effectively pursued in its phase sequence, by the parties. However, the right to an oral hearing also contains the right of the defendant, of the civil party and the party liable under civil law to be present before court. This principle ensures direct contact between the judge and the parties, making the presentation of submissions formulated by the parties to respect a certain order and to facilitate the correct determination of the facts. The Court noted that the regulation of the preliminary chamber concept leads to the idea of judge's impossibility to take evidence at this stage in order to establish the legality of the evidence taken in the prosecution stage, without benefiting from the adversarial aspect and orality, the only possibility for this is the formal finding of the legality of evidence or the need to exclude some of them. [...] However, the preliminary chamber judge's impossibility to take new evidence or to request the submission of certain documents, as well as the lack of an oral hearing on these issues, places the judge in a position to not be able to clarify the situation in fact, an issue that can implicitly interfere with the analysis of law".

From this perspective, the Court noted that "the result of the preliminary chamber procedure regarding the establishment of the legality of evidence and the conduct of procedural acts by the prosecution bodies has a direct influence on the conduct of the trial on the merits, being able to be decisive for determining the guilt / innocence of the defendant. However, covering in this way the preliminary chamber procedure and given the influence that this procedure has on the subsequent phases of the proceedings, the Court noted that the legislature violated the parties' right to a fair trial in its component on the adversarial aspect, orality and equality of arms".

Decision no. 166 of 17 March 2015 on the exception of unconstitutionality of the provisions of Article $549^{1}$ para. (2) of the Code of Criminal Procedure, published in the Official Gazette of Romania, Part I, no. 264 of 21 April 2015.

3. The legal solution according to which the preliminary chamber judge shall adjudicate without the participation of the prosecutor or of the individuals whose assets are to be seized, respectively whose documents are to be annulled is unconstitutional

The legal solution found unconstitutional was enshrined in Article $549^{1}$ para. (3) of the Code of Criminal Procedure, provisions according to which: "After the expiry of the term provided for in paragraph (2), the preliminary chamber judge shall decide on the application by way of a reasoned interlocutory order, in camera, without the participation of the prosecutor or the individuals referred to in paragraph (2), being able to order one of the following solutions: 


\section{Unconstitutional legal solutions...}

a) the judge may reject the proposal and order, where applicable, the restitution of the asset or the annulment of the protective measure taken in view of seizure;

b) the judge may uphold the proposal and order the seisure of the assets or, where applicable, the annulment of the document".

The Court noted that, with the entry into force of the new Code of Criminal Procedure, the annulment of a document is no longer attributed to the civil court, but to the criminal court, i.e. to the preliminary chamber judge, under Article $549^{1}$, as this is one of the special procedures expressly covered by Title IV of the new code.

In the special procedure concerning special confiscation or annulment of a document, the settlement of cases by the preliminary chamber judge takes place in closed session, without the participation of the prosecutor and the persons whose rights or legitimate interests may be affected, and without the possibility to submit evidence, requests and raise exceptions, as they can only submit written notes.

For those reasons and taking into account the fact that the procedure of handling requests on annulment of a forged document, or on special confiscation of a property, related to the substance of the case, the Constitutional Court noted the lack of reasons justifying the absence of public hearings in the procedure subject to constitutional review and therefore noted that the provisions of Article $549^{1}$ of the Code of Criminal Procedure were in breach of the constitutional provisions of Article 21 para. (3) on the right to a fair trial.

On the other hand, in the examined procedure, although the preliminary chamber judge decides on the substance of the case, namely on the essential element of the conflictual relationship - offence, person and guilt -, the persons aggrieve in their interests and the public prosecutor do not have the right to ask for administration of evidence, the use of such evidence and the reliance on exceptions in order to substantiate their position. However, in the light of the right of defence guaranteed by Article 24 of the Constitution, such a situation is unacceptable. The Court considers that the right of defence confers on any party involved in a proceeding and irrespective of nature of proceedings (civil, criminal, commercial, administrative, labour disputes) the possibility of using all the means provided for by law whereby situations or circumstances supporting and adducing evidence for defence may be relied upon. It includes the participation in hearings, the possibility to use any means of evidence, the possibility to request the administration of evidence and to invoke procedural exceptions that may support his position.

Decision no. 166 of 17 March 2015 on the exception of unconstitutionality of the provisions of Article $549^{1}$ para. (3) of the Code of Criminal Procedure, published in the Official Gazette of Romania, Part I, no. 264 of 21 April 2015. 
4. Exclusion of the injured party, the civil party or the party liable under civil law, from being heard before the court of first instance invested with the settlement of the admission of guilt is unconstitutional

The legal solution found unconstitutional was enshrined in Article 484 para. (2) of the Code of Criminal Procedure, provisions according to which: "The court shall adjudicate on the admission of guilt by sentence, following a non-adversarial procedure, in public session, after hearing the prosecutor, the defendant and his lawyer, as well as a civil party, if present".

Article 484 para. (2) of the Code of Criminal Procedure established that the court of first instance shall rule on the settlement agreement through sentence, following a non-contradictory procedure, in public session, after hearing the prosecutor, the defendant and its lawyer, as well as the civil party, if it would appear before the court. The Court found that the court of first instance must rule on the settlement agreement after summoning and hearing the injured party, the civil party and the party liable under civil law who, if, legally summoned, would appear before the court.

Decision no. 235 of 7 April 2015 on the exception of unconstitutionality of the provisions of Article 484 para. (2) of the Code of Criminal Procedure, published in the Official Gazette of Romania, Part I, no. 364 of 26 May 2015.

\section{The suppression of the substantial right of certain participants,}

\section{respectively of the injured party, the civil party and the party liable under}

\section{civil law, to use appeals is unconstitutional}

The legal solution found unconstitutional was enshrined in Article 488 para. (1) of the Code of Criminal Procedure, provisions according to which: "The prosecutor and the defendant may formulate appeal, within 10 days as of communication, against the sentence delivered under Article 485".

The Court found that, unlike the common procedure, in the special procedure of admission of guilt, governed by Articles 478-488 of the Code of Criminal Procedure, under the rule subject to constitutional review, the civil party, the party liable under civil law and the injured party are excluded entirely from the right of appeal, whether in relation to the civil or the criminal aspect of the case.

Therefore, the provisions of Article 488 para. (1) of the Code of Criminal Procedure create inequality of treatment between the injured party, the civil party and the party liable under civil law, on the one hand, and the defendant, on the other hand, in terms of the right to formulate appeal against the judgement by which the court of first 


\section{Unconstitutional legal solutions...}

instance accepts or rejects the settlement agreement, as regards the criminal aspect of the case. This unequal legal treatment is not objectively justified and reasonable, for which reason the criticised text infringes the provisions of Article 16 of the Constitution on equal rights.

Likewise, the Court also found that the right to defence, as provided for in Article 24 of the Constitution, entails also the possibility of exercising the remedies provided for by law against judgements which contain matters of fact or law or solutions which the holder of the right of defence, acting in the capacity of participant in the criminal proceedings, considers incorrect, if they affect his legitimate rights or interests. However, if the injured party, the civil party and the party liable under civil law may not declare appeal on criminal aspects of the case against the judgement accepting or refusing the settlement agreement, they may not defend their rights and interests before the appellate court. For this reason, the provisions of Article 488 para. (1) of the Code of Criminal Procedure infringe the right of defence of the participants in the criminal proceedings, contrary to the constitutional rule in Article 24 para. (1).

As for the provisions of Article 129 of the Constitution, the Court noted that they enshrine the subjective right of the interested parties to exercise remedies against the judgments which they found unlawful or unfounded, a right about which the same constitutional text establishes that it may be exercised "in accordance with the law". Therefore, according to this constitutional text, the legislature may regulate aspects such as the terms for exercising remedies, the substantive conditions and the forms of the actions promoted in this way, the competence of the courts and the trial procedure in order to settle such actions, as well as the solutions which may be delivered for this purpose. Besides, this power of the legislature is provided for in Article 126 (2) of the Basic Law, according to which "the competence of the courts of law and the trial procedure shall be provided only by law". All the more, the legislature may regulate differently the regime of remedies in a special procedure, such as the admission of guilt, in relation to the common regime of remedies, in this case of the appeal. However, this fact does not allow the legislature to abolish the substantive right of an interested party, namely of the injured party, of the civil party and the party liable under civil law, to exercise remedies.

The three categories of participants are persons harmed in their own right by committing the offence, justifying the legitimate interest to participate in the trial, including by declaring the appeal to establish a correct situation in fact and in law in order to establish the truth. This assessment applies whether the procedure of prosecution and judgment of the offence is governed by the rules of common law or by a special procedure.

The Court ascertained and sanctioned accordingly, in this case, the resumption by the legislature, of a solution found unconstitutional by Decision no. 482 of 9 November 2004, published in the Official Gazette of Romania, Part I, no. 1200 of 15 December 2004. 
Decision no. 235 of 7 April 2015 on the exception of unconstitutionality of the provisions of Article 488 of the Code of Criminal Procedure, published in the Official Gazette of Romania, Part l, no. 364 of 26 May 2015.

\section{Conferring a recommendation nature, by way of case-law, to the time}

\section{limit established by the phrase "at least 5 days before the end of the}

\section{period of pre-trial detention" is unconstitutional}

The legal solution found unconstitutional was enshrined in the provisions of Article 235 para. (1) of the Code of Criminal Procedure, "insofar as it is considered that the period of 5 days is a simple indicative time limit and not a mandatory time limit". Those provisions shall read as follows: "The proposal for the extension of the pre-trial detention together with the case-file shall be submitted to the judge of rights and freedoms at least 5 days before the expiry of the length of the pre-trial detention".

The Court held that, in the cases where the proposal for extension of the pre-trial detention is submitted to the court less than 5 days before the end of the duration of the measure, the remaining time until the settlement of the proposal is insufficient for preparing an effective defence, thereby infringing Article 24 of the Constitution and Article 20 of the Basic Law on the provisions of Article 6 para. (3) letter b) of the Convention. This is the more true since the right of defence in the matter of precautionary measures must be exercised effectively, by regulating the term of submission of the proposal for the extension of the duration of pre-trial detention, as the intention of the legislature is to render effective, and not declaratory, i.e. purely theoretical, the compliance with the principle of protection of the freedom of the individual and of the right of defence of the arrested defendant.

On the other hand, the Court held that, where the prosecutor submits to the court the proposal for extension of the pre-trial detention less than 5 days before the end of that period, the time remaining is insufficient for the study of the case by the judge, for the conduct of the hearing and for the handling of the proposal in relation with the provisions on the administration of justice, contained in Article 124 of the Basic Law. However, the Court has held that the reason behind the time limit covered by Article 235 para. (1) of the Code of Criminal Procedure is also to enable the judge to know the case-file as to be able to analyse it and take an informed decision on the request for the extension of the measure involving the deprivation of liberty, in order to remove any arbitrariness in his solution. So, in the absence of sufficient time for the study of the proposal for preventive arrest, the court could give a solution that would not be based on a thorough knowledge of the case, although, as concerns the right of defence of the arrested defendant, not even a shadow of unfairness must exist in the manner in which the rights and freedoms judge decides with regard to the extension of the duration of the measure involving the deprivation of liberty. 


\section{Unconstitutional legal solutions...}

Therefore, the Court held that non-compliance with the deadline for the submission to the rights and freedom judge of the proposal for extension of pre-trial detention "at least 5 days before the end of the period of pre-trial detention" is likely to cause an injury to the right, namely infringement of the right of defence of the defendant held on remand, so that the criminal procedural rules of Article 268 para. (1) of the Code of Criminal Procedure will become applicable, the sanction consisting in the limitation of the public prosecutor's right to file a proposal for the extension of the duration of pre-trial detention and in the incurable nullity of the act of referral deposited after the respective time-limit.

Decision no. 336 of 30 April 2015 on the exception of unconstitutionality of the provisions of Article 235 para. (1) of the Code of Criminal Procedure, published in the Official Gazette of Romania, no. 342 of 19 May 2015.

\section{By the absence of the time limits for which it could be ordered}

and of the maximum duration, the regulation of the preventive measure

consisting in house arrest, a measure that can be taken into the

preliminary chamber and trial procedure at first instance is found

\section{unconstitutional}

The legal solution found unconstitutional, having the marginal name "Duration of the house arrest", was enshrined in Article 222 of the Code of Criminal Procedure.

The Court held that Article 220 of the Code of Criminal Procedure stipulates that the preliminary chamber judge or the court of law handling the case may order, by decision, the defendant's house arrest, upon the prosecutor's reasoned application or ex officio, but without mentioning either the period or the maximum duration which may be ordered for such measure during the two phases of the trial.

The establishment of the measure of house arrest, during the preliminary chamber proceedings and pleadings at first instance, without setting the time limits for which it may be ordered and its maximum duration, does not ensure a fair balance between the public interest and the individual interest, as this measure may be ordered for an unlimited period of time. The principle of proportionality as governed in the particular case of Article 53 of the Constitution presupposes the exceptional nature of the restriction on the exercise of fundamental rights or freedoms, which necessarily involves also their temporary nature. Since public authorities may resort to the restriction on the exercise of certain rights in the absence of other solutions, in order to safeguard basic values of the democratic State, it is logical that this measure must cease as soon as the cause which engendered it ceases (see Decision no. 872 of 25 June 2010, published in the Official Gazette of Romania, Part I, no. 433 of 28 June 2010). This is also 
the meaning given by the Constitutional Court to the provisions of Article 53 of the Basic Law, through its established case-law. Besides, these recitals of principle can be also found in Decision no. 712 of 4 December 2014, published in the Official Gazette of Romania, Part I, no. 33 of 15 January 2015, by which the Court upheld the exception of unconstitutionality of the provisions or Articles 211-217 of the Code of Criminal Procedure, ruling that the measure of the judicial review represents an intrusive measure that may also affect the fundamental right of the individual freedom, as well as the free movement, the personal, family and private life, the freedom of assembly, the right to work and social protection of labour and the economic freedom, so the failure to regulate the time limits and the maximum duration for which the judicial review and the judicial review on bail may be ordered infringes the principle of proportionality, as governed by Article 53 of the Constitution, and which presupposes the exceptional nature of the restriction on the exercise of fundamental rights or freedoms, which necessarily involves also their temporary nature.

In relation to the constitutional provisions referred to, the Court found unconstitutional the rules of criminal procedure of Article 222 entitled "Duration of the house arrest", given that they neither regulate the time limits for which they may be ordered, nor the maximum duration of the measure during preliminary chamber proceedings and pleadings at first instance, where the judicial bodies can order the house arrest measure for unlimited periods of time, consequently restricting, for durations unlimited in time, the exercise of the relevant fundamental rights and freedoms. Thus, according to the constitutionality standards already highlighted, the Court held that such a restriction is unconstitutional, whereas the proportionality principle affects the substance of the fundamental rights concerned, as it does more than restricting their exercise.

Decision no. 361 of 7 May 2015 on the exception of unconstitutionality of the provisions of Article 222 of the Code of Criminal Procedure, published in the Official Gazette of Romania, Part I, no. 419 of 12 June 2015.

8. In line with the requirements of the adversarial principle of the criminal trial, the legal solution under which the appeal concerning the length of criminal proceedings is settled in camera, without the participation of the parties and of the prosecutor is unconstitutional

The legal solution found unconstitutional was enshrined in Article $488^{4}$ para. (5) of the Code of Criminal Procedure, provisions according to which: "Appeal shall be settled through interlocutory order, in camera, without the participation of the parties and of the prosecutor". 


\section{Unconstitutional legal solutions...}

The Court found that the provisions of Article $488^{4}$ para. (5) of the Code of Criminal Procedure stipulate the settlement of the appeal concerning the length of criminal proceedings through interlocutory order, in camera, without the participation of the parties and of the prosecutor.

The Court held that, in this procedure, the participants in the criminal proceedings must have a right to participate in the hearing as to support, before the court, their arguments on the excessive or reasonable length of the criminal proceedings, within an adversarial procedure characterised by orality, otherwise the examined procedure would be in violation of the provisions of Articles 21 para. (3) and 24 of the Constitution.

In this respect, by Decision no. 599 of 21 October 2014, published in the Official Gazette of Romania, Part I, no. 886 of 5 December 2014, the Court found that, by the procedure established by the provisions of Article 341 para. (5) of the Code of Criminal Procedure, the legislature must, besides the obligation to provide for any individual the effective possibility to be able to notify the justice regarding the protection of its rights, freedoms and legitimate interests, this possibility must have a fair character that should confer the fullness of exercise by reaching the objective pursued. This can be achieved through the establishment of procedures that shall comply with the requirements of fairness covered by Article 21 para. (3) of the Constitution without which its content is empty and that the mere right of the person concerned to address to justice acquires a formal aspect as long as specific guarantees of fair trial are not complied with.

By Decision no. 599 of 21 October 2014, the Court also held that the adversarial principle shall allow parties to participate equally in the presentation, discussion and argument against claims made by the other party and to express their opinion on initiatives of the Court for the purposed to find out the truth. The principle is expressed by the maxim audiatur et altera pars. In criminal matters, the adversarial principle expresses also the requirement that the accusation function be separate from the judicial function, being on an equal position with the right of defence. Prosecution and defence combat in court from contradictory positions, so that the authority that decides would reach a correct assessment of evidence. That being so, the trial conducted on the adversarial principle implies equality of arms in both criminal aspects and civil aspects.

The procedure of settlement of the appeal on the length of criminal proceedings, governed by Article $488^{4}$ para. (5) of the Code of Criminal Procedure, respectively in camera, without the participation of the parties and of the prosecutor, is a non-adversarial procedure which cannot provide the procedural guarantees specific to the right to a fair trial and the right of defence.

Decision no. 423 of 9 June 2015 on the exception of unconstitutionality of the provisions of Article $488^{4}$ para. (5) of the Code of Criminal Procedure, published in the Official Gazette of Romania, Part I, no. 538 of 20 July 2015. 
9. The legal solution by which the parties shall be excluded from the examination procedure of the admissibility in principle of the application for review is unconstitutional

The legal solution found unconstitutional was enshrined in Article 459 para. (2) of the Code of Criminal Procedure, provisions according to which: "The admissibility in principle, in camera, shall be examined without summoning the parties".

The Court held that the $a b$ initio exclusion of the applicant in this first stage of the review, considered an extraordinary remedy, and settlement of the admissibility in principle of the application for review only with the participation of the prosecutor places the applicant at a disadvantage vis-à-vis the public prosecutor. Thus, the applicant does not enjoy a real opportunity to comment on what is submitted in law or in fact by the public prosecutor and on what is presented by the latter on the possible exclusion of evidence, the suspension of the enforcement of the judgement subject to review or on the obligations resulting from the initiation of the judicial review. Therefore, by excluding the applicant from this procedure, it is absolutely restricted his possibility to be apprised of and discuss the public prosecutor's submissions, and thus the applicant is placed at a disadvantage vis-à-vis the public prosecutor.

In conclusion, as long as the admissibility in principle of the application for review is settled with the participation of the public prosecutor, with regard to the adversarial procedure, as part of the equality of arms and the right to a fair trial, the Court held that the legal rule must allow the summoning of the parties, and it is sufficient to ensure the parties' participation at this stage of the proceedings, because the judge may decide on the admissibility in principle of the application for review also without the participation of the parties as long as they have been legally summoned whereas, as the Court stated in its case law, the right to an inter partes hearing means, in criminal proceedings, that both the prosecutor and the party must be given the opportunity to have knowledge of and comment on all evidence adduced or on the observations filed by the other party with a view to influencing the court's decision.

Consequently, the legal solution contained in Article 459 para. (2) of the Code of Criminal Procedure, according to which the admissibility in principle of the application for review is examined by the Court "without summoning the parties", is unconstitutional, and is in breach of Article 21 para. (3) of the Basic Law, and therefore, in this procedure in which the public prosecutor participates, the parties must be summoned in order to ensure their possibility to participate at this stage of proceedings.

Decision no. 506 of 30 June 2015 on the exception of unconstitutionality of the provisions of Article 459 (2) of the Code of Criminal Procedure, published in the Official Gazette of Romania, Part I, no. 539 of 20 July 2015. 
Unconstitutional legal solutions...

10. The legal solution by which the admissibility in principle of the appeal for annulment shall be examined without summoning the parties is unconstitutional

The legal solution found unconstitutional was enshrined in Article 431 para. (1) of the Code of Criminal Procedure, provisions under which: "The court shall examine the admissibility in principle, in camera, without summoning the parties".

The Court held that, in the light of the requirements of the right to a fair trial, it is sufficient to ensure the parties' and the injured person's participation at the stage of the proceedings, i.e. admission in principle of the appeal for annulment, which means that the court may decide on the admissibility in principle of the application also in the absence of the parties and the injured person as long as they have been legally summoned.

For these reasons, the Court is to allow the exception of unconstitutionality and to uphold that the legal solution contained in the provisions of Article 431 para. (1) of the Code of Criminal Procedure under which the admissibility in principle of the appeal for annulment is examined by the court "without summoning the parties" is unconstitutional, as it infringes the right to a fair trial enshrined in the provisions of Article 21 para. (3) of the Constitution, in its aspects regarding the equality between prosecution and defence, in terms of the adversarial procedure. Therefore, in the examination procedure of the admissibility in principle of the appeal for annulment, procedure where the prosecutor shall participate, the parties and the injured party shall be summoned.

Decision no. 542 of 14 July 2015 on the exception of unconstitutionality of the provisions of Article 431 para. (1) of the Code of Criminal Procedure, published in the Official Gazette of Romania, Part I, no. 707 of 21 September 2015.

\section{The legal solution according to which the exercise of the function}

verifying the legality to dismiss charges is compatible with the exercise of

\section{the trial function is unconstitutional}

The legal solution found unconstitutional was enshrined in Article 3 para. (3) second sentence of the Code of Criminal Procedure, provisions under which: "In the same criminal trial, the exercise of a judicial function is incompatible with the exercise of other judicial functions, except the one contained in paragraph (1) letter c), which is compatible with the trial function".

The Court found that the provisions of Article 64 para. (5) of the Code of Criminal Procedure provide that the judge who participated in the handling of the complaint 
against decisions not to prosecute or to drop charges may not participate in the same case in the proceedings on the merits or in the appeal proceedings. In other words, the judge is incompatible to sit in the formation of the court not only if he pronounces the interlocutory order to start proceedings, but in any situation where, as pre-trial chamber judge, he has addressed a complaint against the prosecutor's decision not to prosecute or to drop charges, whether he remanded the case for trial or returned the case to the public prosecutor, who after completing the prosecution, ordered the criminal indictment. Moreover, by decision of the High Court of Cassation and Justice no. XV of 22 May 2006, published in Official Gazette of Romania, Part I, no. 509 of 13 June 2006, it has been held that the judge, who, by interlocutory order, allows the complaint, annuls the challenged resolution or order and rules to begin trial, taking the view that the evidence in the file is sufficient to initiate proceedings, becomes incompatible to resolve it on the merits. From a combined interpretation of Article 341 para. (7) point 2 letter c) and Article 64 para. (5) of the Code of Criminal Procedure, the Court found that the pre-trial chamber judge who verifies the lawfulness of the decision to drop charges cannot exercise the trial function.

That is why, pursuant to point 2 of Article 341 para. (7) letter c) of the Code of Criminal Procedure, the judge who orders the initiation of proceedings cannot also sit in court, otherwise Article 21 para. (3) of the Constitution concerning the right to a fair trial, and Article 124 para. (2) of the Basic Law, under which justice is unique, impartial and equal to every individual.

Decision no. 552 of 16 July 2015 on the exception of unconstitutionality of the provisions or Article 3 para. (3) second sentence of the Code of Criminal Procedure, published in the Official Gazette of Romania, Part I, no. 707 of 21 September 2015.

\section{The terminology lacking clarity, precision and predictability, used in}

drafting rules of criminalization is likely to violate the provisions of Article

21 para. (3) of the Constitution, given that the rule concerned can be

\section{interpreted by the courts of law with a wide margin}

The legal solution found unconstitutional was enshrined in Article 223 para. (2) of the Code of Criminal Procedure, provisions under which: "The pre-trial detention measure of the defendant may be also taken if the evidence leads to the reasonable suspicion that he committed a deliberate crime against life, a crime that has caused injury or death to an individual, a crime against national security under the Criminal Code and other special laws, a crime of drug trafficking, arms trafficking, human trafficking, terrorism, money laundering, counterfeiting money or other valuables, extortion, rape, deprivation of liberty, tax evasion, assault, judiciary assault, crime corruption, an offence committed by means of electronic communication or another offence for which the law prescribes imprisonment of 5 years or more and, based on 


\section{Unconstitutional legal solutions...}

assessing the seriousness of the offence, the manner and circumstances of committing it, its entourage and the environment from which it originated, criminal background and other circumstances relating to his person, shows that deprivation of liberty is necessary to eliminate a state of danger to the public order".

The Court noted that, among all the offences contained in Article 223 para. (2) of the Code of Criminal Procedure and which could form the ground of taking the pre-trial detention measure, only those related to drug trafficking and arms trafficking are not defined by the criminal law. In other words, the Romanian criminal law does not regulate the offence of drug trafficking.

The Court concluded that the offence of drug trafficking, which is the subject matter of the present exception of unconstitutionality, is not defined in the Criminal Code or in a special law. The meaning of the term "drug trafficking", used by the legislature in the impugned text, could be deducted only by the combined interpretation of the examined legal provisions, namely Article 2 letter d) of Law no. 339/2005 and point I (1) of the Annex to the law previously mentioned, as well as Article 1 letter b) and Articles 2-10 of Law no. 143/2000. However, the lack of a clear definition of the "drug trafficking" offence is likely to generate different interpretations by the courts, in application of the provisions of Article 223 para. (2) of the Code of Criminal Procedure, in the context of ordering pre-trial detention measure.

The Court found that, as it is the most intrusive of all preventive measures, pre-trial detention measure must be ordered in a clear, precise and foreseeable regulatory framework both for persons subject to this measure and for the prosecution bodies and the courts. Otherwise, one of the essential rights in a State governed by the rule of law, i.e. individual freedom, could be randomly/subjectively restricted. Therefore, in this regulatory context, the requirements on quality, clarity and foreseeability directly and immediately influence the individual right to a fair trial, regarded, in this case, as a guarantee of individual freedom.

The Court held that the lack of clarity, precision and foreseeability of the provision complained of is likely to infringe the provisions of Article 21 para. (3) of the Constitution, given that the person subject to the pre-trial detention measure may not benefit of a fair and equitable trial, since the rule in question can be interpreted by the courts with a wide margin of discretion in terms of the scope of offences for which this measure can be ordered.

Decision no. 553 of 16 July 2015 on the exception of unconstitutionality of the provisions of Article 223 para. (2) of the Code of Criminal Procedure, published in the Official Gazette of Romania, Part I, no. 707 of 21 September 2015. 
13. The inclusion of the "manifestly unfounded" nature between the grounds of inadmissibility of the application for appeal for annulment is unconstitutional

The legal solution found unconstitutional was enshrined in Article 440 para. (2) of the Code of Criminal Procedure, provisions under which: "If the application for appeal for annulment is not submitted within the time limit provided by law or if the provisions of Articles 434, 436 para. (1), (2) and (6), 437 and 438 or if the application is manifestly unfounded, the courts shall reject, by final interlocutory order, the application for appeal for annulment".

The Court noted that the compliance with the right to a fair trial and with the right of defence, referred to in Article 21 para. (3) and Article 24 of the Constitution, requires that the examination of the admissibility of the application for appeal for annulment in the circumstances under consideration, i.e. by adjudication on the manifestly unfounded nature of the application be made during a stage of the proceedings covered by the provisions of Article 440 para. (2) of the Code of Criminal Procedure, i.e. the stage of resolution on the merits of this appeal. Therefore, regardless of the participation of the parties and of the public prosecutor in the procedure of admission in principle of the application for appeal for annulment, this reason for dismissal may not be subject to admission in principle, as it is a specific element of the merits of the extraordinary appeal. The "manifestly unfounded" nature of the application for appeal for annulment does not entitle the legislature to place an aspect related to the merits of the appeal into a previous stage of the proceedings in which the substance of the case is neither dealt with nor settled. The inclusion of the solution of dismissal of the application as manifestly unfounded in the stage of admissibility in principle of the appeal for annulment circumvents the aim and the rationale for such a stage.

For these reasons, the Court found that the expression "if the application is manifestly unfounded" referred to in Article 440 para. (2) of the Code of Criminal Procedure is unconstitutional because the dismissal of the appeal for annulment on the ground that it is manifestly unfounded obliges the supreme court to examine the substance of the case and such may only take place upon settlement on the merits of the appeal for annulment, according to Article 445 of the Code of Criminal Procedure, by summoning the parties and with the participation of the public prosecutor.

Decision no. 591 of 1 October 2015 on the exception of unconstitutionality of the provisions of Article 440 para. (2) of the Code of Criminal Procedure, published in the Official Gazette of Romania, Part I, no. 861 of 19 November 2015. 
Unconstitutional legal solutions...

14. The legal solution according to which the complainant, the prosecutor

and the defendants shall be excluded from the settlement of the complaint

against the solution of non-prosecution or dismissal of charges is

unconstitutional

The legal solution found unconstitutional was enshrined in Article 341 para. (5) of the Code of Criminal Procedure, provisions under which: "The preliminary chamber judge shall decide on the complaint through reasoned interlocutory order, in camera, without the participation of the complainant, the prosecutor and the defendants".

The Court found that the provisions of Article 341 para. (5) of the Code of Criminal Procedure regarding the settlement of the complaint "without the participation of the complainant, the prosecutor and the defendants" are contrary to the right to a fair trial in its aspects on adversarial and oral nature, as both the complainant's complaint and written notes of the prosecutor and of the defendants are likely to influence the solution regarding the dispute which is the subject matter of that procedure, established in terms of confirming/denying the abolishment of the criminal matter.

The case-law of the European Court confirms such an interpretation, in the sense that by Judgment of 9 November 2010 delivered in Case AGVPS-Bacău v. Romania, paragraph 55, the Strasbourg Court identified the existence of an effective damage after finding that the parties concerned were not informed of the conduct of the debates. However, in this case, such an aspect cannot be discussed as long as, by the present decision, the Constitutional Court, censuring the absence of adversarial aspect and orality, established their need during delivery regarding the complaints against the prosecutor's solutions.

Decision no. 599 of 21 October 2014 on the exception of unconstitutionality of the provisions of Article 341 para. (5) of the Code of Criminal Procedure, published in the Official Gazette of Romania, Part I, no. 886 of 5 December 2014.

\section{The legal solution according to which the civil party and the party liable under civil law are not entitled to lodge an appeal regarding the settlement method, in preliminary chamber, of requests and exceptions, is \\ unconstitutional}

The legal solution found unconstitutional was enshrined in Article 347 para. (1) of the Code of Criminal Procedure, provisions according to which: "Within 3 days as of the communication of the interlocutory order provided for in Article 346 para. (1), the prosecutor and the accused may lodge an appeal against the settlement of requests and exceptions, as well as against the solutions provided for in Article 346 para. (3) to (5)". 
The restriction the restriction of the scope of subjects that can bring an appeal before the pre-trial chamber only to the prosecutor and the accused is in breach of the right of access to justice - enshrined in Article 21 of the Basic Law and of Article 6 of the Convention for the protection of human rights and fundamental freedoms - of the civil party and the party liable under civil law, given that, as the Court stated before, the outcome of the procedure for a preliminary ruling on the lawfulness of evidence gathered and procedural acts undertaken by the prosecution has a direct influence on the course of the proceedings on the substance and can be decisive for determining the guilt or innocence of the accused. The Court held that the civil party and the party liable under civil law must enjoy, as the accused and the prosecutor, the right to challenge the decision of the pre-trial chamber judge handed down pursuant to Article 346 para. (1) of the Code of Criminal Procedure on the settlement of requests and exceptions, as well as against the decision to return the case to the Prosecutor's Office - in the case of identification of irregularities of the referral; the total exclusion of evidence gathered during the criminal prosecution; Prosecutor's Office failure to correct in time the irregularities in the referral act - or in relation to the case in which the judge excluded one or more pieces of evidence or invalidated prosecution acts carried out in breach of the law, insofar the evidence excluded may not be taken into account in the proceedings on the substance of the case.

Furthermore, taking into account, on the one hand, the influence of the pre-trial chamber procedure on the subsequent stages of proceedings and, on the other hand, the fact that the decisions referred to in Article 346 para. (3) to (5) of the Code of Criminal Procedure concern all the parties involved in the proceedings, the Court held that also the injured person, as a passive subject in case of perpetration of various criminal offences, and as subject of the criminal law conflict that is the subject of the criminal proceedings, should be given the possibility to lodge an appeal before the pre-trial chamber against the interlocutory order referred to in Article 346 para. (1) of the Code of Criminal Procedure, on the settlement of requests and exceptions, as well as against the decisions provided for in Article 346 para. (3) to (5) of the same Code. This is because, as long as the procedural position of the injured person is that of an active procedural subject in the criminal procedure, having the right to carry out procedural acts during the pre-trial chamber procedure, just as the civil party and the party liable under civil law, according to Article 81 of the Code of Criminal Procedure - i.e. the right to propose the administration of evidence by judicial bodies, to raise exceptions and submit conclusions, to submit any further applications relating to the settlement of the criminal aspects of the case, and to consult the case file.

Decision no. 631 of 8 October 2015 on the exception of unconstitutionality of the provisions of Article 347 para. (1) of the Code of Criminal Procedure, published in the Official Gazette of Romania, Part I, no. 831 of 6 November 2015.

CONSTITUTIONAL LAW REVIEW 


\section{The legal solution according to which the preliminary chamber judge}

\section{shall communicate the requests and exceptions only to the prosecutor,}

\section{excluding the parties, is unconstitutional}

The legal solution found unconstitutional was enshrined in Article 344 para. (4) of the Code of Criminal Procedure, provisions under which: "Upon the expiry of the time limits provided for in paragraphs (2) and (3), the preliminary chamber judge shall communicate requests and exceptions made by defendant or pleas raised by the prosecutor's office of its own motion, which may reply in writing within 10 days after communication".

The Court considered that the defendant does not enjoy a real opportunity to comment on what it is brought forward in law or in fact by the adversary and everything submitted by the latter, being limited only to submitting applications and exceptions after consulting the indictment, and as regards the civil party and the party liable under civil law, the Court notes that they are excluded $a b$ initio from the preliminary chamber procedure. Regulating in this way, the legislature absolutely restricted the possibility for the parties to be apprised of and discuss the pleas raised ex officio and the claims of the prosecutor's office, placing them at a disadvantage as compared with the public prosecutor.

From the perspective of audi alteram partem, as a defining element of equality of arms and the right to a fair trial, the Constitutional Court specifies that the legal rule must enable communication to all parties in criminal proceeding-defendant, civil party, party liable under civil law - of documents that are likely to influence the decision of the judge and to provide all these parties with the possibility to discuss effectively the observations submitted to Court. However, the Court notes that the rules governing the pre-trial chamber procedure merely indicate the persons participating in this stage of the proceedings, i.e. the prosecutor and the defendant only.

Decision no. 641 of 11 November 2014 on the exception of unconstitutionality of the provisions of Article 344 para. (4) of the Code of Criminal Procedure, published in the Official Gazette of Romania, Part I, no. 887 of 5 December 2014.

\section{The legal solution by which the preliminary chamber judge shall}

adjudicate on the requests and exceptions, in camera, without the participation of the prosecutor, the defendant, the civil party and the party

\section{liable under civil law is unconstitutional}

The legal solution found unconstitutional was enshrined in Article 345 para. (1), according to which: "If requests or exception have been formulated or plea raised ex officio, the preliminary chamber judge shall decide on them, through a reasoned interlocutory order, in camera, without the participation of the prosecutor or of the 
defendant, upon the expiry of the time limit provided for in Article 344 para. (4)", respectively in Article 346 para. (1) of the Code of Criminal Procedure, provisions under which: "The preliminary chamber judge shall decide through a reasoned interlocutory order, in camera, without the participation of the prosecutor or of the defendant. The interlocutory order shall be immediately communicated to the prosecutor and to the defendant".

The Court noted that that under certain circumstances the fact that formed the basis for obtaining certain evidence are directly and implicitly relevant on the legality of evidence; however, the impossibility of the preliminary chamber judge to manage new evidence or to request the production of certain documents and the lack of a hearing on these matters, put him in a position not to clarify the facts, which may be reflected implicitly on the analysis of law. In this light, the Court considers that the outcome of the procedure in the preliminary chamber on the legality of evidence gathered and the procedural acts undertaken by the prosecution has a direct influence on the course of the proceedings on the substance and can be decisive for determining the guilt or innocence of the accused. However, regulating in this way the pre-trial chamber procedure and in view of the influence which this has on the subsequent phases of the trial, the Court finds that the legislature infringed the right of the parties to a fair trial in its component concerning the adversarial principle, the oral arguments and equality of arms.

For these reasons, the Court upheld the exception of unconstitutionality and found that the legal solution contained in Article 345 para. (1) and Article 346 para. (1) of the Cod of Criminal Procedure, according to which the preliminary chamber judge rules "without the participation of the prosecutor and the defendant", is unconstitutional, as it does not allow the participation of the prosecutor, the accused, the civil party and the party liable under civil law to proceedings in camera, before the judge of the preliminary chamber. The Court noted that, in the light of the requirements of the right to a fair trial, it is sufficient to ensure that the parties have the possibility to participate at this stage of legal proceedings, and the judge may decide on the outcome of the proceedings in the preliminary chamber also without the participation of the parties as long as they have been legally summoned to appear.

Decision no. 641 of 11 November 2014 on the exception of unconstitutionality of the provisions of Articles 345 para. (1) and 346 para. (1) of the Code of Criminal Procedure, published in the Official Gazette of Romania, Part I, no. 887 of 5 December 2014.

\section{The legal solution by which the preliminary chamber judge shall}

adjudicate on the appeal, without the participation of the parties, the main procedural subjects and the prosecutor is unconstitutional

The legal solution found unconstitutional was enshrined in Article 341 para. (10) of the Code of Criminal Procedure, provisions under which: "The appeal is brought before the judge who settled the complaint and submitted for settlement to the preliminary 


\section{Unconstitutional legal solutions...}

chamber judge from a higher court or when the court notified with the complaint is the High Court of Cassation and Justice, the panel responsible according to the law, which shall adjudicate through a reasoned interlocutory order, without the participation of the prosecutor and the defendant, being able to order one of the following solutions:

a) to reject the appeal as belated, inadmissible or, where appropriate, as unfounded and to maintain the provision of commencement of the trial;

b) to allow the appeal, to abolish the interlocutory order and to rehear the complaint under paragraph (7) point 2, if exceptions to the legality of evidence or to the criminal prosecution had been wrongly settled".

The Court found that this legislative solution was similar to that established by Article 341 para. (5) of the Code of Criminal Procedure and identical with the one established in Article 347 para. (3) in conjunction with Articles 345 para. (1) and 346 para. (1) of the same code, on which, by Decision no. 599 of 21 October 2014 and Decision no. 641 of 11 November 2014, it held that the settlement of the complaint or appeal proceedings without the participation of the parties, main subjects and prosecutor, came against the right to a fair hearing in its components concerning adversarial procedure and oral arguments, as the legal rule did not allow submission by the latter of documents likely to influence the decision of the judge and it did not provide for the opportunity to effectively discuss the observations submitted to the Court. In the light of the right to a fair trial, it is sufficient to ensure the parties' participation in the debates, and the judge may decide on the outcome of the proceedings in the Pre-Trial Chamber also in their absence as long as they have been legally summoned to appear.

Decision no. 663 of 11 November 2014 on the exception of unconstitutionality of the provisions of Article 341 para. (10) of the Code of Criminal Procedure, published in the Official Gazette of Romania, Part I, no. 52 of 22 January 2015.

\section{The restriction on the exercise of fundamental rights or freedoms, for}

\section{an indefinite period of time, is unconstitutional}

The legal solution found unconstitutional was enshrined in Articles 211 to 217 of the Code of Criminal Procedure concerning the judicial review.

The principle of proportionality, as governed in the particular hypothesis of Article 53 of the Constitution, involves the exceptional nature of the restrictions on the exercise of fundamental rights or freedoms, which necessarily also involves their temporary nature. Since public authorities may resort to restrictions on the exercise of certain rights in the absence of other solutions to safeguard the values of the democratic State, it is logical that this serious measure ceased as soon as the cause engendering it ceases too (see Decision no. 872 of 25 June 2010). This is also the 
meaning given to the provisions of Article 53 of the Basic Law by the Constitutional Court, through its case-law. The Constitutional Court established by Decision no. 139 of 14 December 1994, published in the Official Gazette of Romania, Part I, no. 353 of 21 December 1994, that it was unconstitutional to impose for an indefinite period of time the tax on border crossing and by Decision no. 6 of 11 November 1992, published in the Official Gazette of Romania, Part I, no. 48 of 4 March 1993, that it was unconstitutional the prohibition of alienation of real estates owned by the state after 23 August 1944, whereas the transaction in question was affected by an uncertain term, until the adoption by Parliament of a law, according to the provisions under the impugned normative act. Likewise, by Decision no. 2 of 30 June 1992, published in the Official Gazette of Romania, Part I, no. 165 of 16 July 1992, it was found the constitutionality of restricting, 6 months prior to the election date, the exercise of the right to run for the positions of prefect, sub-prefect and management positions in the public services of ministries and decentralized government authorities. At the same time, by Decision no. 291 of 22 March 2007, published in the Official Gazette of Romania, Part I, no. 302 of 7 May 2007, the Constitutional Court ruled as constitutional the restriction to 3 months of free movement abroad of a Romanian citizen returned by a foreign country with which Romania has signed an agreement to that effect. Also, by Decisions no. 872 and no. 874 of 25 June 2010, the Court held the constitutionality of restricting the exercise of the right to work of the personnel paid from public funds. Such measure is in line with the provisions of Article 53 of the Basic Law, only under strict conditions and limited by this constitutional provision.

Decision no. 712 of 4 December 2014 on the exception of unconstitutionality of the provisions of Articles 211 to 217 of the Code of Criminal Procedure, published in the Official Gazette of Romania, Part I, no. 33 of 15 January 2015.

20. The legal solution according to which a complaint formulated by a person who was a suspect cannot be favourably settled against the solution of non-prosecution, if the prosecution is fully completed, but there was an erroneous assessment of the evidence is unconstitutional

The legal solution found unconstitutional was enshrined in Article 341 para. (6) letter c) of the Code of Criminal Procedure, provisions according to which: "In cases where the criminal proceedings was not put into motion, the preliminary chamber judge may order one of the following solutions: (...) c) shall allow the complaint and change the legal grounds of appeal, if this does not create a situation more difficult for the person who made the complaint, as well as in the provisions of Article 341 para. (7) point 2 letter d) of the Code of Criminal Procedure, according to which: "In cases where the criminal proceedings was put into motion, preliminary chamber the judge: (...) 2. shall verify the legality of evidence and criminal prosecution, exclude unlawful evidence given or, where appropriate, sanction according to Articles 280 to 282 the prosecution 
documents made in breach of law and (...) d) shall allow the complaint and change the legal grounds of appeal, if this does not create a situation more difficult for the person who made the complaint".

The Court found that the provisions of Article 341 para. (6) letter c) of the Code of Criminal Procedure are in breach of the principle of free access to justice enshrined in the provisions of Article 21 of the Constitution, by preventing effective access to justice in case the complaint made against the decision to discontinue prosecution by the person who was the suspect, if the evidence is complete and that there is no need to refer the case back to the prosecutor in order to re-open the prosecution. Access to justice for the person who has been suspected, although specifically enshrined in Article 340 para. (1) of the Code of Criminal Procedure, is not effective, since, if prosecution is fully completed, but there has been an incorrect assessment of the evidence, the complaint against the decision to discontinue prosecution, invoking one of the grounds of law entailing the issuance of a decision to close the case, cannot be favourably resolved. Thus, the legitimate interests of the suspect in relation to whom the public prosecutor ordered the discontinuance of prosecution cannot be defended in justice effectively, whereas the decision whereby the prosecutor puts an end to the conflict of criminal law, although it is a way of achieving justice, cannot be censured by the judge in order to restore the legitimate interests infringed.

Having regard to the procedural principle of non reformatio in pejus, the Court found that the provisions of Article 341 para. (7) point 2 letter d) of the Code of Criminal Procedure, which provide, for the situation in which criminal proceedings were put into motion, a legislative solution identical to that laid down in Article 341 para. (6) letter c) of the Code, for the reasons given above, infringe the provisions of Article 21 of the Constitution, by preventing effective access to justice in case the complaint made against the decision of discontinuance of prosecution by the person who was the defendant or party liable under civil law, if the evidence was complete.

Decision no. 733 of 29 October 2015 on the exception of unconstitutionality of the provisions of Article 341 para. (6) letter c) and (7) point 2 letter d) on the Code of Criminal Procedure, published in the Official Gazette of Romania, Part I, no. 59 of 27 January 2016.

\section{The legal solution according to which the duration of the house arrest}

shall not be taken into consideration in calculating the maximum duration

of pre-trial detention measure of the defendant in the course of

\section{prosecution is unconstitutional}

The legal solution found unconstitutional was enshrined in Article para. (10) of the Code of Criminal Procedure, provisions under which: "The duration of deprivation of liberty ordered by the house arrest measure shall not be taken into consideration in calculating the maximum duration of pre-trial detention measure of the defendant in the course of the prosecution". 
The Court found that the measure of the house arrest is similar to pre-trial detention both in terms of their inclusion in the category of precautionary measures and in terms of their nature involving deprivation of liberty, identity of causes and conditions under which the two measures may be ordered and similar method for ordering and extending them. The Court notes, at the same time that, in terms of their assimilation, the location and conditions under which the two precautionary measures are executed has no importance whatsoever.

The Court therefore found that Article 23 para. (5) of the Constitution refers only to the maximum duration of pre-trial detention, which is fully justified in terms of time, given that the measure of the house arrest was regulated by the provisions of Law no. 135/2010, at a later date that the revision of the Basic Law, and that the only precautionary measure involving deprivation of freedom applicable at the time of revision, besides police custody, was pre-trial detention. The Court held, however, that the constitutional rule under examination must be interpreted broadly as limiting, in the course of the prosecution, to 180 days, the maximum length of arrest, whether pre-trial detention or house arrest. That conclusion appears as necessary having regard to the similarity of the two measures in terms of their nature and substance, and this aspect was underlined both by the Constitutional Court and by the European Court of Human Rights in the case-law above cited. In conclusion, the Court finds that the constitutional legislature, upon regulating Article 23 para. (5) of the Basic Law, has in view the limitation of any deprivation of liberty to 180 days, except for police custody, with is separately regulated under paragraph (3) of the Article 23. To allow a cumulation of the duration of the two precautionary measures involving deprivation of liberty that would exceed the maximum time limit of 180 days would be to defeat the constitutional requirements referred to in Article 23 para. (5).

The provisions of Article 222 para. (10) of the Code of Criminal Procedure, which do not allow to take into consideration the duration of the deprivation of liberty ordered by the house arrest measure in calculating the maximum duration of the pre-trial detention of the defendant in the course of the prosecution, are unconstitutional.

Decision no. 740 of 3 November 2015 on the exception of unconstitutionality of the provisions of Article 222 para. (10) of the Code of Criminal Procedure, published in the Official Gazette no. 927 of 15 December 2015.

\section{The legal solution according to which the prosecutor is conferred upon} specific judiciary powers, consisting in delivering certain solutions that are not subject to review by the court of law is unconstitutional

The legal solution found unconstitutional was enshrined in Article 318 of the Code of Criminal Procedure, regarding the cancellation of prosecution.

The Court noted that, according to Article 318 para. (1) of the Code of Criminal Procedure, the prosecutor may cancel the prosecution in case of offences for which the 


\section{Unconstitutional legal solutions...}

law sanctions it by fine or by imprisonment up to 7 years. Analysing from this point of view the requirement regulated in this way, the Court found that it is circumscribed a number of $\mathbf{1 9 8}$ offences out of the total number of $\mathbf{2 3 6}$ offences governed by the Criminal Code, as well as other various offences governed by special laws. By way of example, it falls within this maximum limit of the penalty the manslaughter offences (Article 192 of the Criminal Code), harm to the unborn child (Article 202 of the Criminal Code), illegal deprivation of liberty (Article 205 of the Criminal Code), sexual intercourse with a minor (Article 220 of the Criminal Code), sexual corruption of minors (Article 221 of the Criminal Code), aggravated theft [in criminal variants referred to Article 229 para. (1) and (2) of the Criminal Code], robbery (Article 233 of the Criminal Code), smuggling [Article 263 para. (1) of the Criminal Code], abusive investigation (Article 280 of the Criminal Code) torture [in criminal basic version, referred to Article 282 para. (1) of the Criminal Code], bribery (Article 290 of the Criminal Code), trading in influence (Article 291 of the Criminal Code), embezzlement (Article 295 of the Criminal Code), abuse of power (Article 297 of the Criminal Code), forgery of debt securities or payment instruments (Article 311 of the Criminal Code), coercion of a person to donate organs, tissues or cells of human origin [Article 156 para. (2) of Law no. 95/2006 on healthcare reform, republished in the Official Gazette of Romania, Part I, no. 652 of 28 August 2015], organizing or carrying out the removal of organs, tissues or human cells for transplantation, in order to obtain material benefit (Article 157 of Law no. 95/2006), cultivation, production, manufacturing, experimenting, extracting, preparation, transforming, offering, offering for sale, selling, distributing, delivery of any title, sending, transmission, acquisition, purchase, possession or other operations on the circulation of risk drugs, without the right [Article 2 para. (1) of Law no. 143/2000 on preventing and combating trafficking and illicit drugs, republished in the Official Gazette of Romania, Part I, no. 163 of March 6, 2014], use or presentation in bad faith of false documents or statements, inaccurate or incomplete, if the act results in obtaining of undue funds from the general budget of the European Union or from the budgets managed by it or on its behalf [Article $18^{1}$ para. (1) of Law no. 78/2000 preventing, detecting and sanctioning corruption, published in the Official Gazette of Romania, Part I, no. 219 of 18 May 2000], the change of the destination of the revenue obtained from the general budget of the European Union or from the budgets managed by it or on its behalf, without complying with the legal provisions, [Article $18^{2}$ para. (1) of Law no. 78/2000], the use or presentation in bad faith of false documents or statements, inaccurate or incomplete, resulting in illegal diminution of resources to be transferred to the general budget of the European Union or to the budgets managed by it or on its behalf [Article $18^{3}$ para. (1) of Law no. 78/2000].

Given the reasons previously mentioned, the Court found that, in case of the crimes without injured party, in case of dismissal, following the cancellation by the prosecutor to prosecution, the continuance of the prosecution cannot be required, according to Article 319 of the Code of Criminal Procedure; the solution delivered by the 
prosecutor is not subject to review by the court of law. Therefore, by the regulation of the concept of cancellation to prosecution, in the manner provided for in Article 318 of the Code of Criminal Procedure, the legislature has not achieved an appropriate balance between the principle of legality, specific to the civil law system existing in Romania, and the application of the principle of opportunity, specific to the common law system, giving prevalence to the latter, to the detriment of the former, by regulating the prosecutor's duties of certain specific acts of the judiciary. Thus, under the provisions of Article 318 of the Code of Criminal Procedure, the prosecutor has the possibility to waive the prosecution and therefore to replace the court of law in the administration of justice in the case of approximately three quarters of the total number of offences set out in the Criminal Code and in special laws in force.

The Court held that the waiver of prosecution by the prosecutor, without being subject to review and allowing the court of law, is tantamount to the exercise by it of certain powers that belong to the sphere of competence of courts of law, governed by Article 126 para. (1) of the Constitution, according to which justice shall be exercised by the High Court of Cassation and Justice and by the other courts of law established by law.

Decision no. 23 of 20 January 2016 on the exception of unconstitutionality of the provisions of Article 318 of the Code of Criminal Procedure, published in the Official Gazette of Romania, Part I, no. 240 of 31 March 2016.

\section{The legal solution according to which the prosecutor, the suspect or the defendant or any interested party may appeal only against the way of fulfilling a precautionary measure, by the exclusion of the appeal against \\ taking such measure is unconstitutional}

The legal solution found unconstitutional was enshrined in Article 250 para. (6) of the Code of Criminal Procedure, provisions according to which: "Against the way of fulfilling a precautionary measure taken by the preliminary chamber judge or by the court of, the prosecutor, the suspect or the defendant, or any other interested person may appeal to this judge or to this court of law within 3 days as of the date of execution of the measure".

The Court found that, if the measure was taken during the settlement of the appeal, challenging it is no longer possible as there is no more any remedy. That is, in the light of this new approach, the Court considers it necessary to reconsider the relevant case-law and to uphold the exception of unconstitutionality alleged in this case, for the recitals which are to be mentioned.

Exclusion from immediate judicial review of the order whereby the preliminary chamber judge or the court establishes precautionary measures in criminal proceedings can be regarded as infringing the free access to justice, since, on the one hand, the 


\section{Unconstitutional legal solutions...}

persons concerned are deprived of an effective procedural guarantee for the protection of their right to property affected by the imposition of these measures, and, on the other hand, it adversely affects the substance of the right established by the provisions of Article 21 para. (1) of the Basic Law if the precautionary measure was ordered on appeal. The constitutional principle of free access to justice as to defend the rights and the legitimate interests, as well as the principle of legality that must govern the criminal proceedings, rule out the possibility that the right of every person concerned could be limited to challenging the modality of achievement of the precautionary measure ordered by the preliminary chamber judge, or by a court, since during the criminal proceedings there may be situations where the circumstances referred to in the arrangement of this measure is not in line with the legal requirements, and there is no objective or rational justification for denying the right of the person concerned to go to court to defend his rights.

The lack of a separate appeal against the precautionary measure by the preliminary chamber judge or by the court of law, whether it is a court of first instance or of appeal, is contrary to the right enshrined in Articles 21 para. (1) and (3), 44 and 129 of the Constitution.

Decision no. 24 of 20 January 2016 on the exception of unconstitutionality of the provisions of Article 250 para. (6) of the Code of Criminal Procedure, published in the Official Gazette of Romania, Part I, no. 276 of 12 April 2016.

\section{The legal solution which obliges the court of law to order the}

immediate release of the minor defendant, irrespective of the seriousness

\section{of the offence}

The legal solution found unconstitutional was enshrined in Article 399 para. (3) letter d) of the Code of Criminal Procedure, provisions according to which: "At the same time, the court shall order the immediate release of the defendant who is in pre-trial detention when it: (...) d) an educational measure".

The Court found that the provisions of Article 399 para. (3) letter d) of the Code of Criminal Procedure deprive the court of the opportunity to assess - at the time of settlement, on the merits, of the criminal action, by educational measures involving deprivation of liberty - whether that grounds which led to the measure pre-trial detention still exist or whether there are new grounds justifying such a preventive measure, and to order that pre-trial detention of the accused minor be maintained if he/she has committed a particularly serious offence or multiple offences.

The Court found that the legislative solution laid down in Article 399 para. (3) letter d) of the Code of Criminal Procedure - consisting of the automatic cessation of the pre-trial detention measure and the immediate release of the defendant into custody when the court of first instance institutes an educational measure - is justified only 
when the educational measure taken is non-custodial. By contrast, in the case of settlement, at first instance, of the criminal action, by instituting an education measure involving deprivation of liberty, the legislative solution relating to automatic cessation of the pre-trial detention measure and the forthwith release of the offender in pre-trial detention, infringes the constitutional provisions of Article 1 para. (3) on the rule of law in its components relating to the protection of public policy or public safety - by creating a state of danger for a number of constitutional values, amongst which life and physical and mental integrity, private property and inviolability of the home. Consequently, the Court found that the provisions of Article 399 para. (3) letter d) of the Code of Criminal Procedure are constitutional in so far as they relate only to non-custodial educational measures.

Decision no. 44 of 16 February 2016 on the exception of unconstitutionality of the provisions of Article 399 para. (3) letter d) of the Code of Criminal Procedure, published in the Official Gazette of Romania, Part I, no. 305 of 21 April 2016.

25. The legal solution which does not expressly provide in a clear, precise and predictable way the organs empowered to carry out the actions which represent interferences into the protected field of rights, by the enforcement of a technical surveillance is unconstitutional

The legal solution found unconstitutional was enshrined in Article 142 para. (1) of the Code of Criminal Procedure, provisions under which: "The prosecutor shall enforce an electronic surveillance measure or may order that this be enforced by the criminal investigation body or trained personnel working in the police, or by other specialized state bodies".

The Court held that the phrase "or other specialized state bodies" appears as lacking sufficient clarity, precision and foreseeability to allow subjects to understand which of these organs are empowered to carry out measures with so high a degree of intrusion into the private lives of individuals.

The Court found that no regulations under the national legislation in force, except for Article 142 para. (1) of the Criminal Procedure Code, contain any rule whatsoever affording competencies to some other state body, outside the field of criminal prosecution, to carry out interceptions and to enforce a technical surveillance warrant, respectively. Starting from the particularities of the instant case under review, the Court considers that regulation in this area is only possible by statutory law and not by lower ranking regulations which are adopted by administrative organs instead of the legislative authority, and are characterized by a higher degree of instability or inaccessibility (see Decision no. 17 of 21 January 2015, published in the Official Gazette of Romania, Part I, no. 79 of 30 January 2015, paragraphs 67 and 94). 


\section{Unconstitutional legal solutions...}

Taking into account these arguments and also the intrusiveness of the technical surveillance measures, the Court finds that it is imperative to have such carried out on the basis of a clear legislative framework that is precise and foreseeable for the person who is subject to this measure just like for the criminal prosecution bodies and the courts. Otherwise, it would lead to the possibility of discretionary action in violation of certain fundamental rights which are essential in a State governed by the rule of law: the respect for intimate, family and private life, and the secrecy of correspondence. It is widely accepted that the rights set forth in Article 26 and Article 28 of the Constitution are not absolute rights, yet restraints thereupon must be in compliance with Article 1 para. (5) of the Basic Law, which thus requires a high degree of precision in the terms and concepts used, given the nature of the fundamental rights affected by limitation. Consequently, the constitutional standards of protection for the intimate, family and private life and for the secrecy of correspondence require that such limitation must be achieved through a regulatory framework that determines in a clear, precise and predictable manner which bodies shall be authorized to carry out operations that interfere with the sphere of constitutionally protected rights.

Decision no. 51 of 16 February 2016 on the exception of unconstitutionality of the provisions of Article 142 para. (1) of the Code of Criminal Procedure, published in the Official Gazette of Romania, Part I, no. 190 of 14 March 2016.

\section{The legal solution which does not circumstantiate the revision case for}

\section{the case in which the exception of unconstitutionality was raised, in}

\section{violation of the principle of legal stability, is unconstitutiona}

The legal solution found unconstitutional was enshrined in Article 453 para. (1) letter $\mathrm{f}$ ) of the Code of Criminal Procedure, provisions according to which: "Review of final judgments, regarding the criminal aspect, may be requested when: (...) f) the judgment was based on a legal provision that has been declared unconstitutional after the judgment became final, where the consequences of violating the constitutional provision continue to produce and cannot be remedied by the revision of the judgment".

The Court found that in the examined case for revision - Article 453 para. (1) letter f) of the Code of Criminal Procedure, although the legislature's intention was to give further efficiency to the review of constitutionality, the possibility to benefit from the effects of the decision of unconstitutionality of the Court must be confined to the scope of persons that triggered the review, prior to the publication of the decision, under the conditions laid down by law. To this effect is also the recent case-law of the Court, namely Decision no. 866 of 10 December 2015, paragraph 30, published in the Official Gazette of Romania, Part I, no. 69 of 1 February 2016, according to which, "in the judicial proceedings, the exception of unconstitutionality is part of procedure exceptions intended to prevent a judgement that is based on a legal provision found to 
be unconstitutional. The finding of unconstitutionality of a legal rule due to an exception of unconstitutionality must be beneficial to its authors and may not only be a legal instrument, whereas otherwise it would lose its concrete nature". In those circumstances, having regard to the importance of the principle of res judicata, the Court found that, in order to ensure both the stability of legal relations, and the sound administration of justice, it is necessary that what the Constitutional Court has established in its case-law on the conditions under which the revision procedure can be used, on the basis of a decision allowing the exception of unconstitutionality, be transposed in the criminal procedural rules examined in the present case. Thus, the Court has held that a decision finding the unconstitutionality of a legal provision must be beneficial, in the revision procedure, only to the category of law-seekers who invoked the exception of unconstitutionality in cases definitively resolved until the publication in the Official Gazette of the decision of unconstitutionality, as well as to the authors of that exception, invoked before the publication of the Court's decision, in other cases, definitively resolved, this responding to the need to ensure legal order and stability.

Decision no. 126 of 3 March 2016 on the exception of unconstitutionality of the provisions of Article 453 para. (1) letter $f$ ) of the Code of Criminal Procedure, published in the Official Gazette of Romania, Part I, no. 185 of 11 March 2016.

\section{The legal solution by which the mediation agreement may take legal \\ effects, beyond the time up to which reconciliation may take legal effects,}

is unconstitutional

The legal solution found unconstitutional was enshrined in Article 67 of Law no. 192/2006 on mediation and organizing the mediator profession, in the interpretation given by Decision no. 9 of 17 April 2015 of the High Court of Cassation and Justice - the Panel for the interpretation on points of law on criminal matters, published in the Official Gazette of Romania, Part I, no. 406 of 9 June 2015, provision according to which "in pursuance of the provisions of Article 67 of Law no. 192/2006 on mediation and organizing the mediator profession, the conclusion of a mediation agreement constitutes a sui generis case which removes the criminal liability, distinct from reconciliation; the conclusion of a mediation agreement under the Law no.192/2006 on mediation and organizing the mediator profession may intervene in the course of the criminal trial, until a final criminal decision is delivered".

As concerns the term up to which there may be concluded a mediation agreement regarding the criminal part of the case, although Article 67 of Law no. 192 / 2006 does not provide a certain procedural stage, the Court found that the mediation agreement cannot be concluded at any time in the course of the criminal proceedings, but only as long as the reconciliation can intervene, i.e. until the document instituting the 


\section{Unconstitutional legal solutions...}

proceedings is read, as laid down by Article 159 para. (3) second sentence of the Criminal Code.

The Court found that the provisions of Article 67 of Law no. 192/2006, in the interpretation given by Decision no. 9 of 17 April 2015 of the High Court of Cassation and Justice - the Panel for the interpretation on points of law on criminal matters, are constitutional insofar as the conclusion of a mediation agreement regarding the offences for which there may be reconciliation takes effect only if such conclusion takes place until the document instituting the proceedings is read, otherwise the principle of uniqueness, impartiality and equal justice enshrined in Article 124 para. (2) of the Constitution is infringed.

Decision no. 397 of 15 June 2016 on the exception of unconstitutionality of the provisions of Article 67 of Law no. 192/2006 on mediation and organizing the mediation profession, in the interpretation given by Decision no. 9 of 17 April 2015 of the High Court of Cassation and Justice - The Panel for the interpretation on points of law on criminal matters, published in the Official Gazette of Romania, Part I, no. 532 of $15 \mathrm{July}$ 2016.

\section{The requirement regarding the formulation of the application for} appeal for annulment by a lawyer who may submit conclusions before the High Court of Cassation and Justice is unconstitutional

The legal solution found unconstitutional was enshrined in Article 436 para. (2) of the Code of Criminal Procedure, according to which: "The defendant, the civil party and the party liable under civil law may lodge an application for appeal for annulment only by a lawyer who may submit the conclusions before the High Court of Cassation and Justice", in Article 439 para. $\left(4^{1}\right)$, under which: "If the application for appeal for annulment is not lodged by a lawyer who may submit conclusions before the High Court of Cassation and Justice or it is lodged against a judgment provided for in Article 434 para. (2), the president of the court or the judge delegated by the court shall give back to the party, by administrative way, the application for appeal for annulment", as well as in Article 440 para. (1) and (2) of the Code, under which: "(1) The admissibility of the application for appeal for annulment shall be examined, in camera, by a panel consisting in a judge, after submitting the report of the assistant-magistrate and when the communication procedure is legally fulfilled, without summoning the parties and without the participation of the prosecutor; (2) If the application for appeal for annulment is not lodged within the time limit provided for by law or if the provisions of Articles 434, 436 para. (1), (2) and (5), 437 and 438 are not complied with, the court rejects, by final interlocutory order, the application for appeal for annulment". 
The Court held that this measure is not proportionate to the legitimate aim pursued in terms of the relationship between the general and individual interest invoked, affecting the right of free access to justice and the right of defence. Thus, the Court held, essentially, that access to justice is not an absolute right and may be limited by certain conditions of form and substance imposed by the legislature, in relation to the provisions of Article 21 of the Constitution. These conditions shall not be accepted even if they affect the fundamental right in its very substance. Therefore, the restrictions on the fundamental right are admissible only if it pursues a legitimate aim and there is a relationship of proportionality between the means used by the legislature and the aim sought by it (paragraph 25). By instituting mandatory representation and assistance of the parties by a lawyer as a condition for the admissibility of the exercise of appeal, the legislature has regulated the limits of the free access to justice, an aspect which constitutes an effective state intervention in setting up and structuring this fundamental right. Likewise, the Court also found that, in principle, such state intervention is allowed precisely because of the nature of the right provided for in Article 21 of the Constitution, a right which implies, intrinsically, a state regulation (paragraph 28). As the exercise of the appeals represents one facet of free access to justice and dealing with a state intervention, the Constitutional Court analysed, through the prism of a proportionality test developed in its case-law, if the limits imposed to this right, through the legislature's intervention - namely the regulation of the requirement on the representation and assistance by a lawyer at the procedural stage of the appeal represent a reasonable limitation that is not disproportionate to the aim pursued and does not transform into an illusory/theoretical right. Following the test of proportionality, the Court concluded that the measure of representation and assistance by a lawyer at the procedural stage of the appeal is not proportionate to the aim pursued by the legislature and public benefits are insignificant in relation to the impairment of fundamental rights and freedoms of the individual, respectively those enshrined in Articles 21 and 24 of the Constitution (paragraph 50).

The Court also held that the impugned legal provisions have also affected the right of defence from the perspective of the defendant as a consequence of exercising the right of free access to justice made by the appellant, however, the impugned legal provisions violate Article 24 of the Constitution, a guarantee for the right to a fair trial and from the perspective of the appellant, since this constitutional provision does not aim only at the defence in the trial brought before the court of first instance, but also at the right of defence in the exercise of legal remedies against certain findings of fact or of law or certain solutions adopted by a court of law that are considered wrong by one or other of the parties. If the interested party is prevented from exercising the appeal, he will not be able to make use of and defend his rights before the court of appeal (paragraph 51). In conclusion, the Court held that the obligation representation and assistance by lawyer in order to exercise the appeal is tantamount, on the one hand, to the transformation of the contents of this fundamental right in a condition of 


\section{Unconstitutional legal solutions...}

admissibility of exercising an appeal and, on the other hand, converting this right as an obligation, which affects the substance of the right of defence as set in the Constitution. However, the legislature may not confer upon the right of defence guaranteed by the Constitution meanings which basically contradict its character of guarantee for the right to a fair trial (paragraph 52). The impugned legal solution creates the potential transformation of free access to justice and the right of defence into illusory rights, which is unlikely to lead to continued and natural strengthening of the rule of law, which engages its unconstitutionality (paragraph 54).

Decision no. 432 of 21 June 2016 on the exception of unconstitutionality of the provisions of Articles 436 para. (2), 439 para. (4 $\left.{ }^{1}\right)$ first sentence and 440 para. (1) and (2) of the Code of Criminal Procedure, published in the Official Gazette of Romania, Part I, no. 841 of 24 October 2016.

\section{The exclusion of the judgments delivered by the High Court of}

Cassation and Justice as court of appeal - decisions by which the merits of

the cases was settled - from the exercise of judicial review through the

extraordinary remedy of the appeal for annulment is unconstitutional

The legal solution found unconstitutional was enshrined in Article 434 para. (1) of the Code of Criminal Procedure, according to which: "The judgments delivered by courts of appeal, as courts of appeal, may be appealed by appeal for annulment, (...)".

The Court noted that, in this case, the provisions of Article 434 para. (1) first sentence of the Code of Criminal Procedure are challenged from the perspective of creating discrimination between defendants according to the court which settles the remedy of the appeal - Court of Appeal or the High Court of Cassation and Justice - as those tried on appeal by the supreme court do not benefit from the extraordinary remedy of the appeal for annulment. The Court found that such challenge is founded as the provisions of Article 434 para. (1) first sentence of the Code of Criminal Procedure violate the principles enshrined in Articles 16 and 21 of the Constitution on equal rights, free access to justice and the right to a fair trial given that Article 40 para. (2) of the Code of Criminal Procedure establishes that the High Court of Cassation and Justice shall settle the appeals against the criminal judgments delivered at first by the court of appeal, the military courts of appeal and the Criminal Division of the High Court of Cassation and Justice. Therefore, the fact that the impugned legal provisions exclude the possibility of appealing by appeal for annulment of the judgments delivered by the High Court of Cassation and Justice as court of appeal, decisions by which the merits of the cases was settled, is likely to infringe the equality of rights between citizens regarding the recognition of the fundamental right of free access to justice, in its component on the right to a fair trial. 
The Court found that the provisions of Article 434 para. (1) first sentence of the Code of Criminal Procedure, which exclude the decisions delivered by the High Court of Cassation and Justice as court of appeal - decisions by which the merits of the cases was settled - from exercising judicial review through the extraordinary remedy of the appeal for annulment, violate the constitutional provisions of Article 16 concerning equal rights and of Article 21 on the free access to justice and the right to a fair trial. Where the law the rule of criminal procedure and/or the rule of substantive criminal law - is violated, both the prosecutor and the interested party must be ensured the possibility to request and obtain the restoration of legality by the annulment of the unlawful judgment. However, the impugned legal provisions do not ensure the existence of a remedy for infringements of law and create a regulatory vacuum regarding the annulment of unlawful decisions delivered by the High Court of Cassation and Justice as court of appeal - decisions by which the merits of the cases was settled - depriving, on the one hand, the prosecutor of the necessary instruments for exercising its specific role in criminal proceedings and, on the other hand, the parties of the possibility of defending their rights, freedoms and legitimate interests.

Decision no. 540 of 12 July 2016 on the exception of unconstitutionality of the provisions of Article 434 para. (1) first sentence of the Code of Criminal Procedure, published in the Official Gazette of Romania, Part I, no. 841 of 24 October 2016.

\section{The legal solution allowing the extinction of the preventive measure of judicial review, under different procedural conditions to order such measure, is unconstitutional}

The legal solution found unconstitutional was enshrined in Article $215^{1}$ para. (2) and (5) of the Code of Criminal Procedure, according to which (2): "In the course of the prosecution, judicial review may be extended by the prosecutor, by order, if the grounds which have determined the measure are still maintained or new grounds justifying its extension have appeared; each extension cannot exceed 60 days"; "(5) Against the prosecutor's order by which, as provided for in paragraphs (2) and (3), the judicial review measure has been extended, the defendant may appeal to the judge of rights and freedoms whose court would have the power to judge the case on the merits, as the provisions of Article 213 shall apply accordingly".

Extension of this measure obliges to ensure the procedural guarantees specific to the right of defence. Taking into consideration the contents of this right and the importance of ensuring its enforcement during its order and the extension of preventive measures in the course of the prosecution, exhaustively reviewed by the Constitutional Court by Decision no. 336 of 30 April 2015 whose recitals shall apply mutatis mutandis and on the judicial review measure, the Court noted that it is not only about the 
regulation of the defendant's right to be present and assisted by a lawyer when the prosecutor verifies the grounds that have determined the measure previously mentioned or the emergence of new grounds justifying the extension of this measure, but also about the defendant's right to be heard before the enforcement of this extension.

The Court noted that, in order to ensure the right to defence, the extension of the judicial review measure, according to Article $215^{1}$ para. (2) of the Code of Criminal Procedure, is required to be made by the application of the procedure laid down in Article 212 para. (1) and (3) of the Code of Criminal Procedure for ordering such measure.

Consequently, the provisions of Article $215^{1}$ para. (2) of the Code of Criminal Procedure are constitutional insofar as the extension of the preventive measure of the judicial review is achieved through the application of the procedure to Article 212 para. (1) and (3) of the Criminal Procedure Code on taking the measure of judicial review.

Decision no. 614 of 4 October 2016 on the exception of unconstitutionality of the provisions of Article $215^{1}$ para. (2) and (5) of the Code of Criminal Procedure, published in the Official Gazette of Romania, Part I, no. 962 of 28 November 2016. 